\title{
1-(2-ethoxy-2-oxoethyl)-5-methyl-1H-pyrazole-3-methyl carboxylate
}

\author{
Ahmed Attayibat ${ }^{1, *}$, Smaail Radi ${ }^{1}$, Yahya Lekchiri ${ }^{2}$, Abdelkrim Ramdani ${ }^{1}$ and Maryse Bacquet \\ 3
}

1 Laboratoire de Chimie Organique Physique, Département de Chimie, Université Mohamed $1^{\text {er }}$, BP 524, 60000 Oujda, Morocco

2 Laboratoire de Biochimie, Département de Biologie, Faculté des Sciences, Université Mohamed $1^{\mathrm{er}}$, BP 524, 60000 Oujda, Morocco

3 Laboratoire de Chimie Macromoléculaire, Université des Sciences et Technologies de Lille, 59655

Villeneuve d'Ascq, France

* Author to whom correspondence should be addressed. E-mail: attayibat@yahoo.fr

Received: 20 April 2006 / Accepted: 10 May 2006 / Published: 31 May 2007

Keywords: pyrazole, ethyl bromoacetate
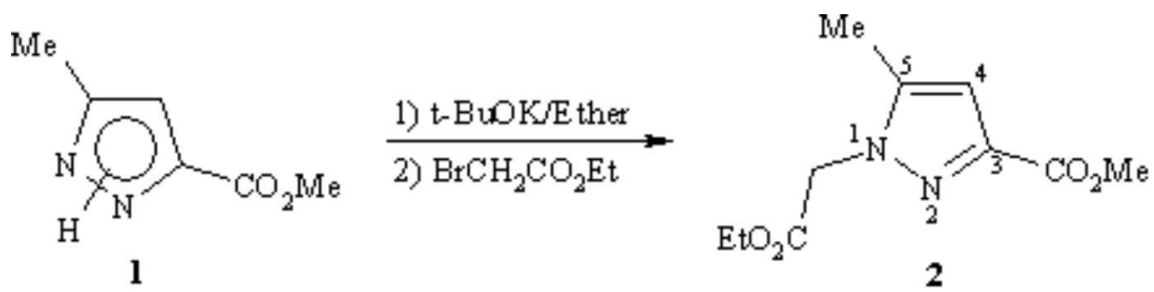

A mixture of $1(2 \mathrm{~g} ; 14.3 \mathrm{mmol})$ and potassium tert-butoxide $(1.68 \mathrm{~g} ; 15 \mathrm{mmol})$ in $80 \mathrm{ml}$ of anhydrous diethyl ether was refluxed for $75 \mathrm{~min}$. After cooling at $0^{\circ} \mathrm{C}$, a solution of ethylbromoacetate $(3.27 \mathrm{~g} ; 19.6 \mathrm{mmol})$ in $15 \mathrm{ml}$ of anhydrous diethyl ether was gradually added. The reaction mixture was stirred for one night at room temperature then filtered and the solvent was eliminated under reduced pressure. The obtained residue was purified on alumina using hexane as eluant to afford a 30\% yield of the new compound 2 (white solid) $(0.97 \mathrm{~g} ; 4.3 \mathrm{mmol})$. The second waited isomer has not been isolated. The product $\mathbf{2}$ was identified on the basis of its spectroscopic data. The coupling constant of the ${ }^{1} \mathrm{H}$ NMR between the proton in position 4 and the methyl group of pyrazol ring ${ }^{4} \mathrm{~J}\left(\mathrm{Me}-\mathrm{H}_{4}\right)$ was $0.71 \mathrm{~Hz}$. This coupling is characteristic of a 5-methyl group [1-3].

Melting point: $54-56^{\circ} \mathrm{C}$

${ }^{1} \mathrm{H}-\mathrm{NMR}\left(\mathrm{CDCl}_{3}, 300 \mathrm{MHz}\right): \delta=6.41(\mathrm{~s}, 1 \mathrm{H}, \mathrm{Pz}-\mathrm{H}) ; 4.80\left(\mathrm{~s}, 2 \mathrm{H}, \mathrm{N}-\mathrm{CH}_{2}-\right) ; 4.15\left(\mathrm{q}, 2 \mathrm{H},-\underline{\mathrm{CH}}_{2}-\mathrm{CH}_{3}\right.$, $\mathrm{J}=7.13 \mathrm{~Hz}) ; 3.78\left(\mathrm{~s}, 3 \mathrm{H},-\mathrm{O}-\mathrm{CH}_{3}\right) ; 2.20\left(\mathrm{~s}, 3 \mathrm{H},-\mathrm{CH}_{3}\right) ; 1.23\left(\mathrm{t}, 3 \mathrm{H}, \mathrm{CH}_{2}-\mathrm{CH}_{3}, \mathrm{~J}=7.13 \mathrm{~Hz}\right)$.

${ }^{13} \mathrm{C}-\mathrm{NMR}\left(\mathrm{CDCl}_{3}, 75 \mathrm{MHz}\right): \delta=168.04 ; 163.45 ; 144.35 ; 142.62 ; 111.61 ; 64.95 ; 54.91 ; 54.22 ; 17.00$; 13.49 .

$\operatorname{IR}\left(\mathrm{KBr}, \mathrm{cm}^{-1}\right): 1715$ and $1735(\mathrm{C}=\mathrm{O})$.

Elemental analysis calculated for $\mathrm{C}_{10} \mathrm{H}_{14} \mathrm{~N}_{2} \mathrm{O}_{4}$ : C 53.09, H 6.24, N 12.38. Found: C 53.42, H 6.22, N 12.07 . 
Mass Spectrometry (ESI): $\mathrm{m} / \mathrm{z}=227(\mathrm{M}+1)$

\section{References:}

1. Tarrago, G.; Ramdani, A.; Elguero, J.; Espada, M. J. Heterocycl. Chem. 1980, 17, 137.

2. Gready, J.E.; Hatton, P.M.; Sternhell, S. J. Heterocycl. Chem. 1992, $29,935$.

3. Kumar, D.; Singh, S.P.; Martinez, A.; Fruchier, A.; Elguero, J.; Martinez-Ripoll, M.; Carrio, J.S.; Virgili, A. Tetrahedron 1995, 51, 4891 .

(C) 2007 by MDPI (http://www.mdpi.org/). Reproduction is permitted for noncommercial purposes. 